\title{
The associations of vitamin D status and dietary calcium with the metabolic syndrome: an analysis of the Victorian Health Monitor survey
}

\author{
Poonam K Pannu' ${ }^{1}$, Yun Zhao ${ }^{2}$, Mario J Soares ${ }^{1, *}$, Leonard S Piers ${ }^{3}$ and Zahid Ansari ${ }^{3}$ \\ ${ }^{1}$ Health Promotion and Disease Prevention, School of Public Health, Curtin Health Innovation Research Institute \\ (CHIRI), Faculty of Health Sciences, Curtin University, GPO Box U1987, Perth, WA 6845, Australia: ${ }^{2}$ Occupation \\ and the Environment, School of Public Health, Faculty of Health Sciences, Curtin University, Perth, WA, Australia: \\ ${ }^{3}$ Health Intelligence Unit, System Intelligence and Analytics Branch, Health Strategy, Productivity and Analytics \\ Division, Department of Health and Human Services, Melbourne, VIC, Australia
}

Submitted 6 November 2015: Final revision received 13 May 2016: Accepted 23 May 2016: First published online 24 June 2016

\begin{abstract}
Objective: To examine the associations between serum 25-hydroxyvitamin D $(25(\mathrm{OH}) \mathrm{D})$, dietary $\mathrm{Ca}$ intake and presence of the metabolic syndrome (MetS).

Design: A stratified cluster sample of a population aged 18-75 years from the Victorian Health Monitor survey.

Setting: Non-institutionalized adults living in private dwellings in Victoria, Australia.

Subjects: Adults ( $n$ 3404) with complete data and without type 1 or type 2 diabetes.

Results: Adjusted for sociodemographic factors, physical characteristics and dietary covariates including Ca intake, every $10 \mathrm{nmol} / 1$ increase in serum 25(OH)D was significantly associated with decreased odds of MetS (adjusted odds ratio $(\mathrm{AOR})=0 \cdot 85,95 \%$ CI $0 \cdot 80,0 \cdot 89 ; P<0 \cdot 001)$. Relative to the low $25(\mathrm{OH}) \mathrm{D}$ tertile (median $33 \mathrm{nmol} / \mathrm{l}$ ), there was a progressive decrease in odds of MetS that reached significance with the high 25(OH)D tertile (median $77 \mathrm{nmol} / \mathrm{l}$; AOR $=0.35,95 \% \mathrm{CI}$ $0 \cdot 26,0 \cdot 48 ; P<0 \cdot 001)$. Every $500 \mathrm{mg} / \mathrm{d}$ increase in Ca intake adjusted for $25(\mathrm{OH}) \mathrm{D}$ did not reduce odds of MetS (AOR $=0.81,95 \%$ CI $0.66,1.06 ; P=0.141$ ) but approached significance if unadjusted for $25(\mathrm{OH}) \mathrm{D}$ in the final model (AOR $=0.81,95 \%$ CI $0.64,1 \cdot 02 ; P=0.073$ ). No significant effect was obtained for tertiles of $\mathrm{Ca}$ intake. However, $\mathrm{Ca}$ and vitamin $\mathrm{D}$ tertile combinations suggested a beneficial effect of high Ca (median $1233 \mathrm{mg} / \mathrm{d}$ ) only at low and medium $25(\mathrm{OH}) \mathrm{D}$. The high $25(\mathrm{OH}) \mathrm{D}$ tertile was associated with significantly decreased odds of MetS regardless of $\mathrm{Ca}$ intake.

Conclusions: A high vitamin D status significantly reduced the odds of MetS. A high $\mathrm{Ca}$ intake may have a similar favourable outcome but only at lower circulating concentrations of $25(\mathrm{OH}) \mathrm{D}$.
\end{abstract}

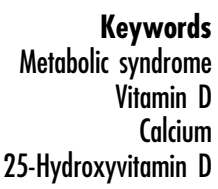

Vitamin $\mathrm{D}$ is a secosteroid that is produced cutaneously through solar UV-B irradiation of 7-dehydrocholesterol present in the skin ${ }^{(1,2)}$. The second source of vitamin D is via food intake and like for $\mathrm{Ca}$, the greatest contribution to intake comes from milk and other dairy products. Vitamin D undergoes two hydroxylation steps, one in the liver and one in the kidney. The final hydroxylation step in the kidney converts 25-hydroxyvitamin D $(25(\mathrm{OH}) \mathrm{D})$ to its active metabolite, 1,25 -dihydroxyvitamin $\mathrm{D}\left(1,25(\mathrm{OH})_{2} \mathrm{D}\right)$, and the enzyme $1-\alpha$-hydroxylase catalyses this conversion ${ }^{(3)}$. Interestingly, expression of the nuclear vitamin D receptor (nVDR) and 1- $\alpha$-hydroxylase is present not only in the kidneys but also many other tissues of the body ${ }^{(4)}$, including the pancreas $^{(2)}$ and immune cells ${ }^{(5-8)}$. Thus many tissues have the ability to locally synthesize $1,25(\mathrm{OH})_{2} \mathrm{D}$ from $25(\mathrm{OH}) \mathrm{D}$ and the potential to contribute to circulating concentrations ${ }^{(4)}$. The active metabolite can then bind to the nVDR, where it forms a heterodimer with the retinoid $\mathrm{X}$ receptor ${ }^{(2)}$. It is now recognized that nVDR regulates approximately $3 \%$ of the human genome $(\sim 700 \text { genes })^{(2,5)}$ and, together with its wide distribution, this provides some foundation for the study of extra-skeletal benefits of vitamin D. 
The metabolic syndrome (MetS) is a clustering of risk factors that greatly increases the risk of CVD and type 2 diabetes mellitus (T2DM). Insulin resistance (IR) is a key player in the development of MetS; however, factors other than IR are also important. Clinical diagnosis of MetS is based on the presence of three or more of the following markers of chronic disease: (i) greater waist circumference; (ii) raised fasting plasma glucose; (iii) hypertension (elevated systolic blood pressure or diastolic blood pressure); and (iv) dyslipidaemia (raised TAG and low HDL cholesterol) ${ }^{(9)}$. The prevalence of MetS in Australia is high with $\sim 30 \%$ of adults classified as having the syndrome ${ }^{(10)}$; a figure comparable to that in other developed countries ${ }^{(11,12)}$. For a sun-drenched country with abundant milk supplies, it is surprising that both vitamin D insufficiency and low $\mathrm{Ca}$ intake are highly prevalent in Australia $^{(13-15)}$. Inadequate vitamin D status has been implicated as a causal factor in many chronic conditions ${ }^{(16)}$


and $\mathrm{IR}^{(23,24)}$. We have previously discussed the potential for $\mathrm{Ca}$ and vitamin $\mathrm{D}$ to regulate body weight ${ }^{(25)}$ and influence the risk of chronic disease ${ }^{(26-29)}$. Documented pathways include Ca's stimulation of fat oxidation, heightened diet-induced thermogenesis, increased faecal fat excretion $^{(27)}$, reduced circulating TAG $^{(30)}$ and the potential for vitamin D to increase resting metabolism ${ }^{(31)}$. Emerging data also support a beneficial effect on IR and $\mathrm{T}_{2} \mathrm{DM}^{(27,32-34)}$. However, a consensus document produced by the Institute of Medicine found little convincing evidence available at the time in support of extra-skeletal effects of vitamin $\mathrm{D}^{(35)}$. The aim of the present study was to investigate whether there was a link between populationbased measures of vitamin D status, dietary Ca intake and the prevalence of MetS.

\section{Methods}

To fulfil our objectives we used a state-wide representative survey of Victorian adults: the Victorian Health Monitor $(\mathrm{VHM})^{(36)}$. The VHM was conducted between May 2009 and April 2010. A stratified cluster sample was selected, based on census collection districts within the eight Victorian Government Department of Health regions. Fifty randomly selected census collection districts were included in the sample, twenty-five from metropolitan and twenty-five from rural Victoria. One eligible person (aged 18-75 years) from each household in each census collection district was randomly selected to participate. The VHM was approved by the Human Research Ethics Committee (HREC) of the Baker IDI Heart and Diabetes Institute, Melbourne, Victoria ${ }^{(37)}$. The analysis of the VHM database was also approved by the HREC at Curtin University (HREC approval number: SPH-19-2014).

The VHM involved an initial household visit to participants to collect demographic information, followed by a participant visit to a local test site to collect risk factor information and undergo biomedical and physical examination. Participants were then asked to complete three $24 \mathrm{~h}$ dietary recall interviews, which were conducted over a 6 -week period. The overall response rate for the VHM was $38 \%$ and a final sample of 3653 participants was achieved.

The response rate in the VHM survey is comparable to similar Australian surveys including the Australian Health Survey: Biomedical Results 2011-12 (response rate $37 \cdot 1 \%)^{(38)}$ and the Australian Diabetes, Obseity and Lifestyle Study (response rate $37 \%)^{(39)}$. To identify any potential selection bias in the VHM between participants and non-participants, key demographic characteristics were compared. A minimal level of difference was found between the two groups ${ }^{(37)}$. Demographic characteristics of participants of the VHM survey were also similar to those from the annual Victorian Population Health Surveys conducted in 2010 ( $n$ 7535) and 2011-12 ( $n$ 33 673) by the Victorian Government, which had response rates of $73 \%{ }^{(40)}$ and $67 \%{ }^{(41)}$, respectively. This would suggest that the level of bias in the VHM is probably no different from that in the larger Victorian Population Health Survey.

Test sites for the collection of biomedical and physical measures were set up specifically for the purposes of the study in census collection districts included in the sample. The procedures used for the biomedical examination were closely aligned with the protocol recommended by the $\mathrm{WHO}^{(42)}$. Participants provided written informed consent upon arrival at test sites and were asked to stay until all tests were complete. Abnormal test results were reviewed by a study doctor who determined whether a result warranted follow-up with a participant. Further details on the survey protocols and procedures can be found in the VHM report $^{(36)}$ and the VHM food and nutrition report ${ }^{(43)}$.

\section{Sample}

In the present study, we excluded: (i) participants with missing glycosylated $\mathrm{Hb}$ (HbA1c) data ( $n$ 31); (ii) those with $\mathrm{HbA} 1 \mathrm{c} \geq 6.7 \%$ as they were classified as having T2DM according to the American Diabetes Association cut-offs $(n \text { 39) })^{(44)}$; (iii) those with diagnosed T2DM ( $n$ 140); (iv) those with type 1 diabetes ( $n$ 9); (v) participants on diabetic medications ( $n$ 25); and (vi) those with missing metabolic components for MetS diagnosis ( $n$ 5). Hence, a total of 3404 participants were included in the analysis. Information on the use of supplements (Ca or vitamin D) was not available in this survey.

\section{Assessment of vitamin $D$ status}

Blood samples were collected via venepuncture after an overnight fast of $10 \mathrm{~h}$ or more. Blood was immediately transported to an accredited central laboratory in Melbourne, Australia. The measurement of serum 25(OH)D concentration was based on the DiaSorin Corporation 
Liaison $^{\circledR} 25(\mathrm{OH}) \mathrm{D}$ total assay. The assay is an automated, direct competitive chemiluminescent immunoassay that measures ergocalciferol (vitamin $\mathrm{D}_{2}$ ) and cholecalciferol (vitamin $\mathrm{D}_{3}$ ) to provide a total value for circulating vitamin $\mathrm{D}$ in nmol/l. The detection limit was $10 \mathrm{nmol} / \mathrm{l}$. The ALTM (All Laboratory Trimmed Mean) was not computed by the laboratory, nor were results compared with a TV ('Target Value') assigned by the NIST (National Institute of Standards and Technology) Reference Measurement Procedure.

\section{Assessment of dietary calcium intake}

Dietary intake data were obtained by multiple-pass $24 \mathrm{~h}$ diet recall using computer-assisted telephone interviews. The first diet recall interview was conducted within 5 to $7 \mathrm{~d}$ of the participants attending the biomedical examination. Two subsequent diet recall interviews were conducted at 2-week intervals following the first diet recall interview. A total of 3653 participants attended and participated in survey components at test sites. Three dietary recalls were conducted, with a total of 10307 dietary recalls completed, where $96 \%$ completed one dietary recall, $94 \%$ completed two dietary recalls and $92 \%$ completed three dietary recalls. Details of the dietary recall and post-interview processing methodology employed are described in the VHM food and nutrition report ${ }^{(43)}$.

All dietary recall interviews were conducted by certified dietitians from the Department of Nutrition and Dietetics, Monash University. Interviewers were trained to assure competency and consistency in collected dietary recall information. Interviewers used a food model book to aid participants with their description of portion sizes of the foods and beverages they had consumed. The food model book prompted dietary recall by including frequently forgotten foods and eating occasions, and assisted with portion size estimation with 'to scale' photographs of food and beverage containers, measuring spoons and cups ${ }^{(43)}$.

The FoodWorks ${ }^{\circledR}$ nutrition software (FoodWorks ${ }^{\circledR}$ Interview) was employed for implementation of dietary recalls. The dietary recall used a multiple-pass approach to assist participants to sufficiently recall their food and beverage intakes. The software includes a scripted guide for interviewers to help prompt participants for food recall in each interview. Interviewers were able to interrupt and prompt for further details on food items if required. Further information on the multiple-pass dietary recall process has been described in detail in the VHM food and nutrition report ${ }^{(43)}$.

On completion of the interviews, volume conversion factors were developed to convert food volumes into food weights. Conversions of food volumes to weights were done by 'reference to published data, by measuring the weight and volume of specific foods, or by considering the food as very similar to another food for which a volume conversion factor was already available ${ }^{(43)}$. The AUSNUT
$2007^{(45)}$ nutrient composition data were used to calculate nutrient intakes based on estimated food intakes. The mean intake for each nutrient was computed for each participant based on information collected from three $24 \mathrm{~h}$ dietary recalls and was used in the analysis. This information was used to get a single measure of nutrient intake for each participant ${ }^{(43)}$.

\section{Physical activity level}

The following criteria were used to define each participant's level of physical activity: (i) sufficiently physically active ( $\geq 150 \mathrm{~min}$ of 'physical activity time' per week); (ii) insufficiently physically active (1-149 min of 'physical activity time' per week); and (iii) physically inactive (0 min of 'physical activity time' per week) ${ }^{(36)}$. 'Physical activity time' was calculated as the sum of the time spent walking or performing moderate activity plus double the time spent in vigorous physical activity (to reflect its greater intensity) ${ }^{(46)}$

\section{Antbropometric measurements}

Anthropometric measurement methods for weight, height and waist circumference have been previously described in the VHM report ${ }^{(36)}$

\section{Biomedical measurements}

Blood collection was conducted via venepuncture after an overnight fast of $10 \mathrm{~h}$ or more. Blood samples were assessed for the following factors: total cholesterol, HDL cholesterol, TAG, Hba1c and fasting plasma glucose levels. Blood samples were centrifuged on site and were analysed at a separate central laboratory on a Siemens ADVIA 2400 Clinical Chemistry System. Blood components were measured as following: total cholesterol using enzymatic (oxidase/peroxidase) methods; HDL cholesterol using the elimination/catalase method; TAG using the GPO Trinder reagent set with serum blank; blood glucose using the hexokinase method; and HbA1c was measured by immunoassay (Roche Integra chemistry analyser) ${ }^{(36)}$.

\section{Blood pressure measurements}

Sitting blood pressure measurements (GE Dinamap 8100 Vital Signs Monitor) were performed in triplicate on each participant, after a rest period of $5 \mathrm{~min}$. The average of the two closest measurements $(<10 \mathrm{mmHg}$ for systolic blood pressure and $<6 \mathrm{mmHg}$ for diastolic blood pressure) were used in the analysis. Further details have been presented in the VHM report ${ }^{(36)}$.

\section{Classification of metabolic syndrome}

MetS was classified according to the criteria from the joint interim statement of several major organizations ${ }^{(9)}$. Individuals were classified as having MetS if they had 
three or more of the following five components: (i) elevated TAG $\geq 1.7 \mathrm{mmol} / 1$ ( $\geq 150 \mathrm{mg} / \mathrm{dl}$ ); (ii) reduced HDL-C $<1.0 \mathrm{mmol} / 1(<40 \mathrm{mg} / \mathrm{dl})$ in males and $<1.3 \mathrm{mmol} / \mathrm{l}$ $(<50 \mathrm{mg} / \mathrm{dl})$ in females, or on lipid-lowering therapy; (iii) hypertension (systolic blood pressure $\geq 130 \mathrm{mmHg}$ and/or diastolic blood pressure $\geq 85 \mathrm{mmHg}$ ), or on antihypertensive medications; (iv) elevated fasting plasma glucose $\geq 5.6$ to $6.9 \mathrm{mmol} / \mathrm{l}$ ( $\geq 100$ to $124 \mathrm{mg} / \mathrm{dl}$ ) but free of diabetes; and (v) elevated waist circumference $\geq 94 \mathrm{~cm}$ for males or $\geq 90 \mathrm{~cm}$ for Aboriginal and Torres Strait Islander, Asian and South American males and $\geq 80 \mathrm{~cm}$ for females. In the current analysis participants were categorized into having or not having MetS (yes/no).

\section{Statistical analysis}

The main outcome variable was the status of MetS (yes/no). The primary exploratory variables of interest were serum 25(OH)D concentration and Ca intake, which were both categorized into tertiles: low 25(OH)D (range 10-44 nmol/1; median $33 \mathrm{nmol} / \mathrm{l})$, medium 25(OH)D (range $45-65 \mathrm{nmol} / \mathrm{l}$; median $54 \mathrm{nmol} / \mathrm{l}$ ) and high 25(OH)D (range 65-204 nmol/1; median $77 \mathrm{nmol} / \mathrm{l}$ ); and low Ca (range $72-719 \mathrm{mg} / \mathrm{d}$; median $579 \mathrm{mg} / \mathrm{d}$ ), medium Ca (range $720-1009 \mathrm{mg} / \mathrm{d}$; median $858 \mathrm{mg} / \mathrm{d}$ ) and high Ca (range $1010-3726 \mathrm{mg} / \mathrm{d}$; median $1233 \mathrm{mg} / \mathrm{d}$ ). The association between all possible combinations of serum $25(\mathrm{OH}) \mathrm{D}$ concentration and $\mathrm{Ca}$ intake tertiles (thereby nine levels in total) and MetS was examined in the present study, with mutual adjustment for the other components. Serum $25(\mathrm{OH}) \mathrm{D}$ concentration was also tested as a continuous variable for every $10 \mathrm{nmol} / \mathrm{l}$ increment, while Ca intake was tested as a continuous variable for every $500 \mathrm{mg} / \mathrm{d}$ increment.

In the first stage of the analysis, demographic statistics and differences between the serum $25(\mathrm{OH}) \mathrm{D}$ concentration and $\mathrm{Ca}$ intake tertiles were tested by the independentsamples $t$ test and frequency tabulation. Furthermore, to investigate the effect of the categorical predictors of interest on the risk of having MetS and higher value of its components, a $\chi^{2}$ test and simple binary logistic regression analysis were then conducted to obtain the crude unadjusted odds ratios and corresponding 95\% confidence intervals.

Multiple logistic regression analysis was then carried out to calculate the adjusted odds ratios (AOR) and 95\% confidence intervals for the relationships between serum $25(\mathrm{OH}) \mathrm{D}$ concentration or $\mathrm{Ca}$ intake and having MetS. Analyses were conducted using the statistical software package IBM SPSS Statistics for Windows, Version 21.0. Complex samples analysis was applied to adjust for the unequal selection probability due to the multistage stratified cluster-sampling procedure used in the VHM survey. Appropriate clustering and weighting variables were used to compute appropriate standard errors and confidence intervals in the complex samples analysis procedure.
A $P$ value of less than 0.05 was accepted as statistical significance.

\section{Confounders}

In our analysis we considered and tested several risk modifiers, based on our experience ${ }^{(47)}$ and that of others $^{(18,48-50)}$. Accordingly we included the following demographic factors: weight, age, gender, country of birth, income, education level, physical activity level, smoking status and season. Dietary factors included intakes of: alcohol, dietary fibre, energy, $\mathrm{Mg}$, retinol, 25(OH)D concentration ( $\mathrm{Ca}$ intake model only) and $\mathrm{Ca}$ intake $(25(\mathrm{OH}) \mathrm{D}$ concentration model only). Age, weight, alcohol, dietary fibre, energy intake, $\mathrm{Mg}$, retinol, 25(OH)D concentration and $\mathrm{Ca}$ intake were entered into the regression model as continuous variables. Country of birth was identified according to those born in Australia and those born overseas. Education level was categorized according to three levels: tertiary education, TAFE/diploma/certificate and high school or less. Smoking status was assessed on the basis of three categories: current smoker, ex-smoker and non-smoker. Income levels were categorized according to four categories: $\geq \$ A U$ 70000, \$AU 30001-70000, $<\$ A U 30000$ and don't know/refused. Season of biomedical examination was categorized as summer, autumn, winter and spring.

\section{Rationale of analysis}

In the current analysis we examined the relationship of serum 25(OH)D concentration and $\mathrm{Ca}$ intake on MetS through a series of questions that resulted in different models:

1. What was the unadjusted relationship between $25(\mathrm{OH}) \mathrm{D}$ and $\mathrm{Ca}$ intake with MetS? (crude model).

2. What was the confounding influence of sociodemographic factors on the relationship of $25(\mathrm{OH}) \mathrm{D} / \mathrm{Ca}$ intake with MetS? (model 1).

3. What was the potential influence of dietary factors on the relationship of $25(\mathrm{OH}) \mathrm{D} / \mathrm{Ca}$ intake with MetS? (model 2).

\section{Results}

The present study population consisted of a total of 3404 adults with a mean age of 49 years. The overall prevalence of MetS was $21.6 \%$, with a larger proportion of males (22\%) having MetS than females $(14 \% ; P<0.001)$. The mean serum $25(\mathrm{OH}) \mathrm{D}$ concentration of those with MetS was $49.6 \mathrm{nmol} / 1$, significantly lower than that of participants without MetS which was $57.5 \mathrm{mmol} / 1 \quad(P<0 \cdot 001)$. The mean dietary Ca intake was $849 \mathrm{mg} / \mathrm{d}$ in those with MetS and $926 \mathrm{mg} / \mathrm{d}$ in those without MetS $(P<0 \cdot 001$; Table 1). 
Table 1 Demographic and clinical characteristics by the presence/absence of metabolic syndrome (MetS) among non-diabetic adults ( $n$ 3404) aged 18-75 years from the Victorian Health Monitor survey, May 2009-April 2010

\begin{tabular}{|c|c|c|c|c|c|c|c|c|c|}
\hline \multirow[b]{2}{*}{ Characteristic } & \multicolumn{4}{|c|}{ Absence of MetS ( $n$ 2669) } & \multicolumn{4}{|c|}{ Presence of MetS ( $n$ 735) } & \multirow[b]{2}{*}{$P$ value } \\
\hline & $n$ & $\%$ & Mean & SE & $n$ & $\%$ & Mean & SE & \\
\hline Age (years) & & & 41 & 0.9 & & & 52 & 1.0 & $<0.001$ \\
\hline Weight $(\mathrm{kg})$ & & & $75 \cdot 7$ & 0.5 & & & $91 \cdot 6$ & 0.8 & $<0.001$ \\
\hline \multicolumn{9}{|l|}{ Gender } & $<0.001$ \\
\hline Male & 1237 & 78 & & $2 \cdot 0$ & 344 & 22 & & $2 \cdot 0$ & \\
\hline Female & 1565 & 86 & & $1 \cdot 1$ & 257 & 14 & & $1 \cdot 1$ & \\
\hline \multicolumn{9}{|l|}{ Country of birth } & 0.541 \\
\hline Born in Australia & 2139 & 82 & & 1.4 & 454 & 18 & & 1.4 & \\
\hline Born overseas & 658 & 81 & & $2 \cdot 0$ & 153 & 19 & & $2 \cdot 0$ & \\
\hline \multicolumn{9}{|l|}{ Education level } & $<0.001$ \\
\hline Tertiary education & 1136 & 87 & & 1.5 & 170 & 13 & & 1.5 & \\
\hline TAFE/diploma/certificate & 580 & 80 & & $2 \cdot 3$ & 140 & 20 & & $2 \cdot 3$ & \\
\hline High school or less & 1075 & 78 & & 1.7 & 303 & 22 & & 1.7 & \\
\hline \multicolumn{9}{|l|}{ Income } & 0.098 \\
\hline$\geq \$ A U ~ 70001$ & 1341 & 84 & & 1.4 & 250 & 16 & & 1.4 & \\
\hline \$AU $30001-70000$ & 837 & 79 & & $2 \cdot 1$ & 220 & 21 & & $2 \cdot 1$ & \\
\hline$<\$ A U 30000$ & 456 & 81 & & $2 \cdot 6$ & 110 & 19 & & $2 \cdot 6$ & \\
\hline Don't know/refused & 157 & 82 & & 3.8 & 33 & 18 & & 3.8 & \\
\hline \multicolumn{9}{|l|}{ Physical activity level } & 0.011 \\
\hline Sufficient physical activity ( $\geq 150 \mathrm{~min} /$ week) & 1929 & 83 & & 1.5 & 384 & 17 & & 1.5 & \\
\hline Insufficient physical activity (<149 min/week) & 704 & 81 & & 1.9 & 168 & 19 & & 1.9 & \\
\hline Inactive (0 min/week) & 153 & 71 & & 4.8 & 62 & 29 & & & \\
\hline \multicolumn{9}{|l|}{ Smoking status } & $<0.001$ \\
\hline Current smoker & 423 & 80 & & $2 \cdot 5$ & 109 & 20 & & 2.5 & \\
\hline Ex-smoker & 694 & 75 & & $2 \cdot 1$ & 224 & 25 & & $2 \cdot 1$ & \\
\hline Non-smoker & 1669 & 85 & & 1.4 & 283 & 15 & & 1.4 & \\
\hline \multicolumn{9}{|l|}{ Season of biomedical examination } & 0.182 \\
\hline Summer & 155 & 75 & & $5 \cdot 2$ & 52 & 25 & & $5 \cdot 2$ & \\
\hline Autumn & 677 & 84 & & $2 \cdot 0$ & 131 & 16 & & 2.0 & \\
\hline Winter & 964 & 84 & & 1.8 & 182 & 16 & & 1.8 & \\
\hline Spring & 991 & 80 & & $2 \cdot 8$ & 252 & 20 & & $2 \cdot 8$ & \\
\hline \multicolumn{10}{|l|}{ Vitamin D status } \\
\hline Serum 25(OH)D (nmol/l) & & & $57 \cdot 5$ & $2 \cdot 1$ & & & $49 \cdot 6$ & $2 \cdot 1$ & $<0.001$ \\
\hline $25(\mathrm{OH}) \mathrm{D}$ tertile & & & & & & & & & $<0.001$ \\
\hline Low $25(\mathrm{OH}) \mathrm{D}(33 \mathrm{nmol} / \mathrm{l}) \dagger$ & 857 & 77 & & $2 \cdot 1$ & 252 & 23 & & $2 \cdot 1$ & \\
\hline Medium 25(OH)D $(54 \mathrm{nmol} / \mathrm{l}) \dagger$ & 925 & 80 & & $2 \cdot 3$ & 237 & 21 & & $2 \cdot 3$ & \\
\hline High 25(OH)D $(77 \mathrm{nmol} / \mathrm{l}) \dagger$ & 1013 & 89 & & 1.3 & 120 & 11 & & 1.3 & \\
\hline \multicolumn{10}{|l|}{ Dietary variables } \\
\hline Dietary $\mathrm{Ca}$ intake $(\mathrm{mg} / \mathrm{d})$ & & & $926 \cdot 0$ & $11 \cdot 4$ & & & $849 \cdot 0$ & $20 \cdot 0$ & $<0.001$ \\
\hline Ca tertile & & & & & & & & & 0.001 \\
\hline Low Ca intake $(579 \mathrm{mg} / \mathrm{d}) \dagger$ & 847 & 77 & & 1.8 & 245 & 23 & & 1.8 & \\
\hline Medium Ca intake $(858 \mathrm{mg} / \mathrm{d}) \dagger$ & 908 & 83 & & 1.4 & 187 & 17 & & 1.4 & \\
\hline High Ca intake $(1233 \mathrm{mg} / \mathrm{d}) \dagger$ & 924 & 85 & & 1.5 & 163 & 15 & & 1.5 & \\
\hline Total energy intake $(\mathrm{kJ} / \mathrm{d})$ & & & 9768 & 134 & & & 9442 & 163 & 0.021 \\
\hline Alcohol (g/d) & & & $12 \cdot 3$ & 0.7 & & & $15 \cdot 3$ & 0.9 & $<0.001$ \\
\hline Dietary fibre $(\mathrm{g} / \mathrm{d})$ & & & $26 \cdot 5$ & 0.4 & & & $25 \cdot 3$ & 0.5 & 0.006 \\
\hline $\mathrm{Mg}(\mathrm{mg} / \mathrm{d})$ & & & 418.9 & $6 \cdot 6$ & & & $397 \cdot 2$ & 7.6 & 0.008 \\
\hline Retinol $(\mu \mathrm{g} / \mathrm{d})$ & & & 433.8 & 23.2 & & & 454.5 & $56 \cdot 1$ & 0.428 \\
\hline \multicolumn{10}{|l|}{ Metabolic components } \\
\hline Waist circumference $(\mathrm{cm})$ & & & $86 \cdot 4$ & 0.7 & & & $102 \cdot 5$ & 0.7 & $<0.001$ \\
\hline Fasting plasma glucose $(\mathrm{mmol} / \mathrm{l})$ & & & 4.9 & 0.02 & & & 5.5 & 0.04 & $<0.001$ \\
\hline HDL cholesterol $(\mathrm{mmol} / \mathrm{l})$ & & & 1.5 & 0.02 & & & $1 \cdot 2$ & 0.02 & $<0.001$ \\
\hline $\mathrm{TAG}(\mathrm{mmol} / \mathrm{l})$ & & & $1 \cdot 1$ & 0.02 & & & $2 \cdot 1$ & 0.06 & $<0.001$ \\
\hline Systolic blood pressure $(\mathrm{mmHg})$ & & & 122 & 0.7 & & & 136 & 0.9 & $<0.001$ \\
\hline Diastolic blood pressure $(\mathrm{mmHg})$ & & & 71 & 0.5 & & & 81 & 0.4 & $<0.001$ \\
\hline
\end{tabular}

Data are presented as mean estimate (weighted) \% for categorical variables, and mean estimate (weighted) and SE for continuous variables. Differences in the continuous and categorical variables between groups were assessed by the independent-samples $t$ test and the $x^{2}$ test, respectively. †Median of the tertile group.

Association between tertiles of serum 25-bydroxyvitamin $D$ concentration, calcium intake and presence of metabolic syndrome

Every $10 \mathrm{nmol} / 1$ increment in serum 25(OH)D concentration reduced the likelihood of having MetS by $15 \%$ (model 2; Table 2). The crude model indicated that those in the highest tertile of serum 25(OH)D concentration had a $60 \%$ lower odds of having MetS. After adjusting for sociodemographic variables (model 1), the significant inverse association between serum 25(OH)D 
Table 2 Odds ratio of having metabolic syndrome by tertiles of serum 25-hydroxyvitamin D (25(OH)D) concentration among non-diabetic adults $(n$ 3404) aged 18-75 years from the Victorian Health Monitor survey, May 2009-April 2010

\begin{tabular}{|c|c|c|c|c|c|c|}
\hline & \multicolumn{2}{|c|}{ Crude model } & \multicolumn{2}{|c|}{ Model 1} & \multicolumn{2}{|c|}{ Model 2} \\
\hline & COR & $95 \% \mathrm{Cl}$ & AOR & $95 \% \mathrm{Cl}$ & AOR & $95 \% \mathrm{Cl}$ \\
\hline $\begin{array}{l}\text { 25(OH)D, continuous }(10 \mathrm{nmol} / \mathrm{l}) \\
P \text { value }\end{array}$ & 0.87 & $0.82,0.92$ & 0.82 & $\begin{array}{l}0.78,0.85 \\
01\end{array}$ & 0.85 & $<0.001$ \\
\hline \multicolumn{7}{|l|}{ 25(OH)D tertile } \\
\hline Low 25(OH)D $(33 \mathrm{nmol} / \mathrm{l}) \dagger$ & \multicolumn{2}{|c|}{ Ref. } & \multicolumn{2}{|c|}{ Ref. } & \multicolumn{2}{|c|}{ Ref. } \\
\hline Medium 25(OH)D $(54 \mathrm{nmol} / \mathrm{l}) \dagger$ & 0.87 & $0.66,1 \cdot 14$ & $0.69^{*}$ & $0.52,0.90$ & 0.77 & $0.58,1.04$ \\
\hline High $25(\mathrm{OH}) \mathrm{D}(77 \mathrm{nmol} / \mathrm{l}) \dagger$ & $0.40^{*}$ & $0.29,0.56$ & $0 \cdot 29^{*}$ & $0.22,0.38$ & $0.35^{*}$ & $0.26,0.48$ \\
\hline$P$ value for trend & \multicolumn{2}{|c|}{$<0.001$} & \multicolumn{2}{|c|}{$<0.001$} & \multicolumn{2}{|c|}{$<0.001$} \\
\hline
\end{tabular}

COR, crude odds ratio; AOR, adjusted odds ratio; Ref., lowest 25(OH)D tertile served as the reference group.

Model 1: adjusted for age, gender, country of birth, income, education, smoking and season.

Model 2: adjusted for model 1 covariates plus energy intake, physical activity level, body weight, alcohol, dietary fibre, Mg, Ca and retinol.

*Significant in comparison to the reference group at $5 \%$ significance level.

†Median of the tertile group.

Table 3 Odds ratio of having metabolic syndrome by tertiles of dietary calcium intake among non-diabetic adults $(n 3404)$ aged $18-75$ years from the Victorian Health Monitor survey, May 2009-April 2010

\begin{tabular}{|c|c|c|c|c|c|c|}
\hline & \multicolumn{2}{|c|}{ Crude OR } & \multicolumn{2}{|c|}{ Model 1} & \multicolumn{2}{|c|}{ Model 2} \\
\hline & COR & $95 \% \mathrm{Cl}$ & AOR & $95 \% \mathrm{Cl}$ & AOR & $95 \% \mathrm{Cl}$ \\
\hline $\begin{array}{l}\text { Ca intake, continuous }(500 \mathrm{mg} / \mathrm{d}) \\
P \text { value }\end{array}$ & \multicolumn{2}{|c|}{0.002} & \multicolumn{2}{|c|}{0.004} & \multicolumn{2}{|c|}{$0 \cdot 141$} \\
\hline \multicolumn{7}{|l|}{ Ca tertile } \\
\hline Low Ca $(579 \mathrm{mg} / \mathrm{d}) \dagger$ & \multicolumn{2}{|c|}{ Ref. } & \multicolumn{2}{|c|}{ Ref. } & \multicolumn{2}{|c|}{ Ref. } \\
\hline Medium Ca $(858 \mathrm{mg} / \mathrm{d}) \dagger$ & $0.71^{*}$ & $0.56,0.90$ & $0.73^{*}$ & $0.56,0.96$ & 0.92 & $0.63,1.33$ \\
\hline High Ca $(1233 \mathrm{mg} / \mathrm{d}) \dagger$ & $0.61^{*}$ & $0.46,0.81$ & $0.63^{\star}$ & $0.46,0.86$ & 0.83 & $0.56,1.21$ \\
\hline$P$ value for trend & \multicolumn{2}{|c|}{0.002} & \multicolumn{2}{|c|}{0.012} & \multicolumn{2}{|c|}{0.613} \\
\hline
\end{tabular}

COR, crude odds ratio; AOR, adjusted odds ratio; Ref., lowest Ca tertile served as the reference group.

Model 1: adjusted for age, gender, country of birth, income, education, smoking and season.

Model 2: adjusted for model 1 covariates plus energy intake, physical activity level, body weight, alcohol, dietary fibre, Mg and 25-hydroxyvitamin D concentration.

*Significant in comparison to reference group at $5 \%$ significance level.

†Median of the tertile group.

concentration and presence of MetS remained. After adjustment for dietary variables (alcohol, dietary fibre, energy, $\mathrm{Mg}, \mathrm{Ca}$ and retinol), participants in the highest $25(\mathrm{OH}) \mathrm{D}$ tertile had a $65 \%$ lower odds of having MetS compared with those in the lowest 25(OH)D tertile (model 2; Table 2).

Table 3 shows that every $500 \mathrm{mg} / \mathrm{d}$ increment in dietary Ca intake reduced the likelihood of having MetS by $25 \%$ after adjusting for sociodemographic variables in model 1 , but the reduction became non-significant after adding dietary variables (alcohol, dietary fibre, energy, $\mathrm{Mg}$ and serum 25(OH)D concentration) in model 2. If we did not control for serum $25(\mathrm{OH}) \mathrm{D}$ in the latter model, the AOR approached significance $(\mathrm{AOR}=0.81,95 \% \mathrm{CI}$ 0.64, 1.02; $P=0.073)$ but was non-significant on controlling for 25(OH)D (Table 3, model 2; $P=0 \cdot 141$ ). Those in the highest tertile of dietary $\mathrm{Ca}$ intake had significantly reduced odds of having MetS by 39\% in the crude model and $37 \%$ in model 1 in comparison with those in the lowest tertile of dietary $\mathrm{Ca}$ intake; however, the comparison was not significant when dietary factors were added to model 2 (Table 3). Based on previous evidence we tested for potential interactions between serum 25(OH)D concentration, $\mathrm{Ca}$ intake and age, gender, smoking status, physical activity, county of birth and education level; however, no significant interactive effects were found ${ }^{(13)}$. Furthermore, interactions between serum $25(\mathrm{OH}) \mathrm{D}$ concentration, Ca and dietary variables (alcohol, dietary fibre, energy, $\mathrm{Mg}$ and retinol) were tested but none were significant.

\section{Association between combined effects of serum 25-bydroxyvitamin $D$ concentration and calcium intake and presence of metabolic syndrome}

In view of finding no significant interaction between serum $25(\mathrm{OH}) \mathrm{D}$ status and $\mathrm{Ca}$ intake $(P=0.651)$, the regression analysis was extended to examine the effect of combining serum $25(\mathrm{OH}) \mathrm{D}$ concentration and Ca intake tertiles on MetS (Fig. 1). The combination of low serum 25(OH)D tertile (median $33 \mathrm{nmol} / \mathrm{l}$ ) and low $\mathrm{Ca}$ intake tertile (median $579 \mathrm{mg} / \mathrm{d}$ ) was the reference group. After controlling for confounding factors, the combination of high serum 25(OH)D and low, medium or high Ca intake significantly reduced the odds of having MetS by 72,70 and $66 \%$, respectively (Fig. 1). 


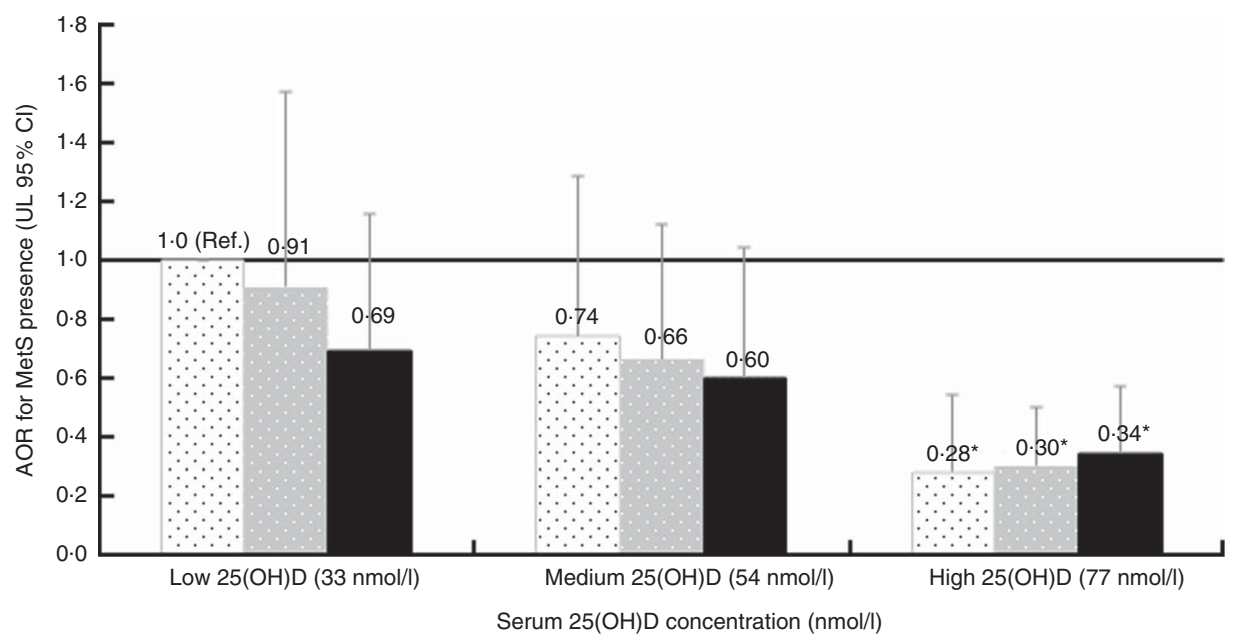

Fig. 1 Combined effects of serum 25-hydroxyvitamin $\mathrm{D}(25(\mathrm{OH}) \mathrm{D})$ concentration (median of the tertile group given in parentheses) and dietary calcium intake ( $\square$, low calcium, median $579 \mathrm{mg} / \mathrm{d}$; $\square$, medium calcium, median $858 \mathrm{mg} / \mathrm{d}$; $\square$, high calcium, median $1233 \mathrm{mg} / \mathrm{d}$ ) on the presence of metabolic syndrome (MetS) among non-diabetic adults ( $n$ 3404) aged 18-75 years from the Victorian Health Monitor survey, May 2009-April 2010. Adjusted odds ratios (AOR), with the upper limit (UL) of the $95 \%$ confidence interval represented by vertical bars, adjusted for age, gender, country of birth, income, education, smoking, season, physical activity level, weight, alcohol, dietary fibre, magnesium, retinol and energy intake. 'Ref.' indicates that the lowest 25(OH)D and lowest calcium tertile served as the reference group; *significant in comparison to reference group at $5 \%$ significance level

\section{Discussion}

We investigated the individual and combined association of serum $25(\mathrm{OH}) \mathrm{D}$ concentration with dietary Ca intake on MetS. In addition to many confounders, we controlled for Ca intake in the $25(\mathrm{OH}) \mathrm{D}$ model and for $25(\mathrm{OH}) \mathrm{D}$ concentration in the $\mathrm{Ca}$ model, to investigate their effect, independent of each other. The results of this representative sample of adults from an Australian state have indicated that higher serum $25(\mathrm{OH}) \mathrm{D}$ concentration per se was associated with significantly reduced odds of MetS (Table 2). However, this was not statistically significant for every model of $\mathrm{Ca}$ intake tested (Table 3 ). As a continuous variable the overall pattern for $\mathrm{Ca}$ was in the same direction as $25(\mathrm{OH}) \mathrm{D}$ and with a lower AOR (Table 3). If we did not control for $25(\mathrm{OH}) \mathrm{D}$ in the Ca intake continuous model, the AOR approached significance $(\mathrm{AOR}=0.81$, $95 \%$ CI $0.64,1.02 ; P=0.073)$ but on controlling for 25(OH)D (Table 3, model 2; $P=0 \cdot 141$ ), this was nonsignificant. Such outcomes suggest that prevailing serum $25(\mathrm{OH}) \mathrm{D}$ concentrations could modulate the potential effect of Ca on MetS.

Our findings are consistent with other cross-sectional and prospective studies where an inverse association between 25(OH)D concentration, Ca intake and MetS was observed $^{(18,19,48,51-53)}$. One cross-sectional study found a $67 \%$ reduction in the odds of having MetS among those in the highest $25(\mathrm{OH}) \mathrm{D}$ tertile $(68-231 \mathrm{nmol} / \mathrm{l}) v$. the lowest tertile $(9-45 \mathrm{nmol} / \mathrm{l})^{(48)}$. Our study obtained relatively similar results where the highest tertile of $25(\mathrm{OH}) \mathrm{D}$ was found to contribute a $65 \%$ reduced odds for MetS in comparison to the lowest tertile (Table 2). The study by Hypponen et $a l^{(48)}$ had double the sample size but adjusted only for gender, month and hour of blood measurement. In comparison we controlled for additional sociodemographic, anthropometric and dietary covariates. A more recent prospective study in the elderly also found an inverse association between MetS and high 25(OH)D $(\geq 75 \mathrm{nmol} / \mathrm{l})$, although the magnitude of their findings was much lower ${ }^{(53)}$. Furthermore, a large prospective study reflected our results and found a $36 \%$ reduction in odds of having MetS in the highest $\mathrm{Ca}$ intake group $(1005-2596 \mathrm{mg} / \mathrm{d})$ in comparison to the lowest Ca group. Overall, despite differences between such studies in sample sizes, study design (cross-sectional $v$. prospective), age of subjects and confounders used, the protective effect of vitamin $\mathrm{D}$ in reducing the odds of having MetS appears consistent.

We also examined the potential additive effects of tertile combinations of serum $25(\mathrm{OH}) \mathrm{D}$ concentration and $\mathrm{Ca}$ intake on MetS (Fig. 1). The outcomes were interesting since they suggested that at low and medium tertiles of $25(\mathrm{OH}) \mathrm{D}$, there was a trend for increasing $\mathrm{Ca}$ intake to reduce AOR of MetS (Fig. 1). However, in the highest $25(\mathrm{OH}) \mathrm{D}$ tertile this trend disappeared, with significantly reduced AOR across the range from low to high $\mathrm{Ca}$ intakes. This was suggestive of a plateau effect, raising the possibility of a threshold to the interplay between $\mathrm{Ca}$ and $25(\mathrm{OH}) \mathrm{D}$ on functional outcomes.

It is now well known that increasing $\mathrm{Ca}$ intake increases passive $\mathrm{Ca}$ absorption from the gastrointestinal tract ${ }^{(54)}$. A higher $\mathrm{Ca}$ intake also increases the half-life of $25(\mathrm{OH}) \mathrm{D}$ in circulation ${ }^{(55)}$ and together these actions may explain the effect of high $\mathrm{Ca}$ in the lowest 25(OH)D tertile (Fig. 1). However, a key physiological function of $25(\mathrm{OH}) \mathrm{D}$ is the maintenance of $\mathrm{Ca}$ homeostasis via active intestinal $\mathrm{Ca}$ 
absorption $^{(54,56,57)}$. So an improvement in vitamin D status from the low to medium tertile (Fig. 1) would further increase active $\mathrm{Ca}$ absorption and possibly allow for a greater effect of $\mathrm{Ca}$ on MetS. In support of such a paradigm was the observation that the overall effect of $\mathrm{Ca}$ in the medium $25(\mathrm{OH}) \mathrm{D}$ tertile was stronger than in the low 25(OH)D tertile (Fig. 1). While 25(OH)D and Ca absorption have a positive relationship, there is a plateau to this effect. Above $\sim 80 \mathrm{nmol} / \mathrm{l}$, active $\mathrm{Ca}$ absorption does not respond to further increases in $25(\mathrm{OH}) \mathrm{D}^{(54)}$. It is notable that the latter concentration falls within the highest tertile of $25(\mathrm{OH}) \mathrm{D}$ in the present study and may explain why increasing $\mathrm{Ca}$ intake ceases to have any added benefit in the highest tertile (Fig. 1).

There is another related and important facet to these relationships. A raised parathyroid hormone concentration is associated with an increased risk of $\operatorname{MetS}^{(29,58,59)}$. Increases in dietary $\mathrm{Ca}$ and in serum $25(\mathrm{OH}) \mathrm{D}$ would lower circulating parathyroid hormone. Recent data have described the exponential decline in parathyroid hormone with increases in $25(\mathrm{OH}) \mathrm{D}^{(60)}$. The analysis indicated two inflection points in the relationship, with the second plateau at 25(OH)D concentrations above $\sim 70 \mathrm{nmol} / \mathrm{l}$ where parathyroid hormone was maximally suppressed ${ }^{(60)}$. We acknowledge that this threshold value of $25(\mathrm{OH}) \mathrm{D}$ is not universally accepted $^{(61)}$ and that further work is necessary. However, it serves the argument that, at the highest tertile of $25(\mathrm{OH}) \mathrm{D}$ in the present study, the negative effects of a raised parathyroid hormone level on MetS could be significantly diminished relative to the previous tertiles. Overall, our results argue that $\mathrm{Ca}$ intake has an added effect with 25(OH)D on reducing MetS, but this applies only up to the medium tertile of $25(\mathrm{OH}) \mathrm{D}$ (Fig. 1). Above the latter the observed effects are due mainly to $25(\mathrm{OH}) \mathrm{D}$ per se. There is some evidence in the literature in support of threshold effects, especially for outcomes that impinge on MetS. A randomized controlled trial has demonstrated that following vitamin D supplementation, significant increases in insulin sensitivity (HOMA\%S) were observed only in those who achieved a $25(\mathrm{OH}) \mathrm{D}$ concentration of $80 \mathrm{nmol} / \mathrm{l}$ and had maintained that value for 6 months $^{(24)}$. In a weight-loss randomized controlled trial, participants who achieved $80 \mathrm{nmol} / \mathrm{l}$ at 12 months demonstrated significantly greater losses in weight, percentage fat mass and waist circumference, compared with those who did not ${ }^{(62)}$. We cannot predict the threshold value of $25(\mathrm{OH}) \mathrm{D}$ from our study. Moreover, as the outcomes of these randomized controlled trials were derived from post hoc analyses, they only support the hypothesis rather than validate an $80 \mathrm{nmol} / 1$ cut-off.

\section{Potential mechanisms}

There are many mechanistic pathways to support our observations of a protective effect of 25(OH)D concentrations on MetS. An animal study suggests an independent effect of $25(\mathrm{OH}) \mathrm{D}$ on $\beta$ cells, with improvements in impaired glucose tolerance and insulin secretion, despite prevailing plasma Ca concentrations ${ }^{(63)}$. $1,25(\mathrm{OH})_{2} \mathrm{D}$ has a role in insulin secretion ${ }^{(64)}$, where it stimulates the expression of the insulin receptor and increases the responsiveness to glucose transport. During vitamin $\mathrm{D}$ deficiency $\beta$-cell function is inhibited, leading to a decrease in insulin secretion ${ }^{(65)}$. In addition, inadequate $25(\mathrm{OH}) \mathrm{D}$ concentration is associated with $\mathrm{IR}^{(66-68)}$. While we acknowledge that IR does not always explain all of $\operatorname{MetS}^{(69-71)}$, it is a key feature in the pathophysiology of the syndrome ${ }^{(72)}$. The nVDR and $1-\alpha$-hydroxylase enzyme are found in tissues not related Ca metabolism, such as in cardiac myocytes, endothelial and smooth vascular muscle cells ${ }^{(70)}$; potentially underscoring a role of $25(\mathrm{OH}) \mathrm{D}$ in cardiovascular health. The renin-angiotensin system is important in the regulation of blood pressure ${ }^{(73)}$ and low $25(\mathrm{OH}) \mathrm{D}$ concentration may dysregulate control of the renin-angiotensin system ${ }^{(71)}$. In this context lower $25(\mathrm{OH}) \mathrm{D}$ concentration has been found to be inversely correlated with measures of arterial stiffness and also to increased arterial resistance, hypertension and endothelial dysfunction $^{(74-77)}$. Moreover higher vitamin D status could also reduce islet $\beta$-cell damage by reducing islet renin-angiotensin system activity, thereby reducing the risk of hyperglycaemia ${ }^{(78)}$.

The beneficial effect of Ca on features of MetS may arise from both its absorbed fraction and its unabsorbed fraction in the gastrointestinal tract ${ }^{(27)}$. There is now increasing evidence that $\mathrm{Ca}$ intake may influence fat balance and hence energy balance. Dietary Ca increases whole-body fat oxidation and this could, potentially, reduce circulating fatty acids/lipids ${ }^{(27,79)}$. Unabsorbed $\mathrm{Ca}$ is not without metabolic effects ${ }^{(27)}$. A meta-analysis indicates that for dairy Ca intake of $\sim 1200 \mathrm{mg} / \mathrm{d}$, an increase of $\sim 5 \mathrm{~g} / \mathrm{d}$ in faecal fat can be expected ${ }^{(80)}$. This arises from the interaction of non-absorbed $\mathrm{Ca}$ and dietary fat in the gastrointestinal lumen, leading to Ca-fatty acid soap formation and hence its eventual excretion. These outcomes may contribute to lower circulating TAG and other lipid fractions seen with Ca supplementation ${ }^{(30)}$. Finally, as with other chronic non-communicable conditions, MetS is a low-grade chronic inflammatory state. We, and others, are of the opinion that adequate vitamin $\mathrm{D}$ has a significant role in ameliorating the inflammatory state in chronic disease $\mathrm{e}^{(8,81,82)}$.

\section{Study limitations}

The cross-sectional design has permitted only an examination of associations between Ca intake, vitamin D status and MetS. Although we have controlled for recognized confounders, we cannot establish which came first, lower $25(\mathrm{OH}) \mathrm{D}$ concentration and $\mathrm{Ca}$ intake or having MetS. An increased requirement for these nutrients in chronic conditions like MetS is a possibility and may account for a 
reverse causation. Unlike some European countries, there is no mandatory fortification of the Australian food supply for these nutrients. Unfortunately the VHM survey did not include information on $\mathrm{Ca}$ and vitamin $\mathrm{D}$ supplement usage. Such information would have potentially allowed us to tease out the effect of food-derived Ca and sunlightderived vitamin D status (since vitamin D in Australian foods is low) $v$. pharmacological intake. However, we approached the potential confounding effect of supplement $\mathrm{Ca}$ intake by using random generated surrogate data for different age groups, based on the Ca supplement intake percentages collected in the Australian Health Survey 2011-12 $2^{(83)}$. We found that the change between crude and adjusted effect estimates was much less than $10 \%$; a cut-off criterion for being a sizeable confounder in epidemiology research ${ }^{(84)}$. Hence, we do not anticipate significant confounding by supplement-derived Ca intake on the association between dietary $\mathrm{Ca}$ intake and the risk of MetS in the current study.

Serum $25(\mathrm{OH}) \mathrm{D}$ can be affected by genetic variation of the major transporter, the vitamin D-binding protein ${ }^{(85-87)}$. This is seen as variations in vitamin D-binding protein concentration $^{(86,88)}$ as well as some vitamin D-binding protein phenotypes potentially having stronger binding abilities than others ${ }^{(89)}$. Serum $25(\mathrm{OH}) \mathrm{D}$ can also differ due to genetic variation in its key activation enzyme, CYP27B1 ${ }^{(90)}$, that converts $25(\mathrm{OH}) \mathrm{D}$ to the active form. Such genetic variant information was not collected in the VHM survey so is a potential confounding factor. Future studies in this area could include this information to provide a more complete picture.

A small proportion of our sample was from South Asia ( $1.6 \%, n 56)$, an ethnic group associated with high rates of betel nut chewing. Chewing betel nut could increase the risk of developing $\mathrm{T}_{2} \mathrm{DM}^{(91)}$ and animal studies have indicated that betel nut ingestion in male parents may contribute to inheritable glucose intolerance in their offspring $^{(92)}$. Such data are not available for Australia and were not collected as part of the VHM survey. However, exclusion of these cases ( $n$ 56) did not change the direction or magnitude of our results. We therefore anticipate minimal confounding from such a potential habit in our South Asian participants.

\section{Study strengths}

We have used a large, representative, population-based sample of one Australian state that covered an age range 18-75 years. The dietary data were collected through a multiple-pass $24 \mathrm{~h}$ dietary recall which is the current standard and all blood analysis was conducted centrally by one laboratory based on standard methodology. Our analysis has considered and adjusted for many sociodemographic and nutrient confounders, with further adjustment for energy intake. We acknowledge that this field of research would benefit from the confirmation of a causal role for $\mathrm{Ca}$ and vitamin $\mathrm{D}$ in MetS. While randomized controlled trials provide Level 1 evidence, they are not necessarily the mainstay of the evidence base for public health nutrition and in deciding nutrition priorities for better health ${ }^{(93,94)}$.

\section{Conclusions}

The present study demonstrates that high serum 25(OH)D concentration was associated with significant reductions in the odds of MetS. We raise the possibility that the benefit of $\mathrm{Ca}$ is restricted to low and medium serum $25(\mathrm{OH}) \mathrm{D}$ concentrations, and this may represent a threshold to the interplay between $\mathrm{Ca}$ and $25(\mathrm{OH}) \mathrm{D}$ on functional outcomes. Overall, these population-based results contribute to the evidence in favour of a role for vitamin D and $\mathrm{Ca}$ in modulation of MetS risk.

\section{Acknowledgements}

Acknowledgements: M.J.S. acknowledges the School of Public Health, Curtin University for research infrastructure and support, and the Victorian Department of Health and Human Services for use of the VHM survey data set. The authors thank the reviewers and the editorial board for their constructive comments. The opinions and analysis in this manuscript are those of the authors and not those of: the Department of Health and Human Services, Victoria; the Victorian Government; the Secretary to the Department of Health Victoria or the Victorian Minister for Health. Financial support: P.K.P. is the recipient of an Australian Postgraduate Award. Conflict of interest: None. Authorship: P.K.P. analysed data and wrote the first draft. M.J.S. generated the idea, planned the analysis and co-wrote the manuscript. Y.Z. cross-checked the analysis and co-wrote the manuscript. L.S.P. and A.Z. critically reviewed all aspects of the manuscript. Ethics of human subject participation: The VHM was approved by the Human Research Ethics Committee (HREC) of the Baker IDI Heart and Diabetes Institute, Melbourne, Victoria. The analysis of the VHM database was also approved by the HREC at Curtin University (HREC approval number: SPH-19-2014).

\section{References}

1. Liu J (2012) Vitamin D content of food and its contribution to vitamin D status: a brief overview and Australian focus. Photochem Photobiol Sci 11, 1802-1807.

2. Pilz S, Kienreich K, Rutters F et al. (2013) Role of vitamin D in the development of insulin resistance and type 2 diabetes. Curr Diab Rep 13, 261-270.

3. Wamberg L, Christiansen T, Paulsen SK et al. (2013) Expression of vitamin D-metabolizing enzymes in human adipose tissue - the effect of obesity and diet-induced weight loss. Int J Obes (Lond) 37, 651-657. 
4. Dusso AS, Brown AJ \& Slatopolsky E (2005) Vitamin D. Am J Physiol Renal Physiol 289, F8-F28.

5. Bouillon R, Carmeliet G, Lieben L et al. (2014) Vitamin D and energy homeostasis - of mice and men. Nat Rev Endocrinol 10, 79-87.

6. Hossein-Nezhad A, Mirzaei K, Keshavarz SA et al. (2013) Evidences of dual role of vitamin D through cellular energy homeostasis and inflammation pathway in risk of cancer in obese subjects. Minerva Med 104, 295-307.

7. Neve A, Corrado A \& Cantatore F (2013) Immunomodulatory effects of vitamin D in peripheral blood monocytederived macrophages from patients with rheumatoid arthritis. Clin Exp Med 14, 275-283.

8. Calton EK, Keane KN \& Soares MJ (2015) The potential regulatory role of vitamin $\mathrm{D}$ in the bioenergetics of inflammation. Curr Opin Clin Nutr Metab Care 18, 367-373.

9. Alberti KG, Eckel RH, Grundy SM et al. (2009) Harmonizing the metabolic syndrome: a joint interim statement of the International Diabetes Federation Task Force on Epidemiology and Prevention; National Heart, Lung, and Blood Institute; American Heart Association; World Heart Federation; International Atherosclerosis Society; and International Association for the Study of Obesity. Circulation 120, $1640-1645$.

10. Cameron AJ, Magliano DJ, Zimmet PZ et al. (2007) The metabolic syndrome in Australia: prevalence using four definitions. Diabetes Res Clin Pract 77, 471-478.

11. Beltran-Sanchez H, Harhay MO, Harhay MM et al. (2013) Prevalence and trends of metabolic syndrome in the adult US population, 1999-2010. J Am Coll Cardiol 62, 697-703.

12. Grundy SM (2008) Metabolic syndrome pandemic. Arterioscler Thromb Vasc Biol 28, 629-636.

13. Daly RM, Gagnon C, Lu ZX et al. (2012) Prevalence of vitamin $\mathrm{D}$ deficiency and its determinants in Australian adults aged 25 years and older: a national, populationbased study. Clin Endocrinol (Oxf) 77, 26-35.

14. Nowson CA, McGrath JJ, Ebeling PR et al. (2012) Vitamin D and health in adults in Australia and New Zealand: a position statement. Med J Aust 196, 686-687.

15. Australian Bureau of Statistics (2014) Australian Health Survey: Nutrition First Results - Food and Nutrients, 2011-12. Canberra: ABS.

16. Peterlik M, Boonen S, Cross HS et al. (2009) Vitamin D and calcium insufficiency-related chronic diseases: an emerging world-wide public health problem. Int J Environ Res Public Health 6, 2585-2607.

17. Brock KE, Huang WY, Fraser DR et al. (2011) Diabetes prevalence is associated with serum 25-hydroxyvitamin D and 1,25-dihydroxyvitamin D in US middle-aged Caucasian men and women: a cross-sectional analysis within the Prostate, Lung, Colorectal and Ovarian Cancer Screening Trial. Br J Nutr 106, 339-344.

18. Brenner DR, Arora P, Garcia-Bailo B et al. (2011) Plasma vitamin D levels and risk of metabolic syndrome in Canadians. Clin Invest Med 34, E377-E384.

19. Gagnon C, Lu ZX, Magliano DJ et al. (2012) Low serum 25 -hydroxyvitamin $D$ is associated with increased risk of the development of the metabolic syndrome at five years: results from a national, population-based prospective study (The Australian Diabetes, Obesity and Lifestyle Study: AusDiab). J Clin Endocrinol Metab 97, 1953-1961.

20. Anderson JL, May HT, Horne BD et al. (2010) Relation of vitamin D deficiency to cardiovascular risk factors, disease status, and incident events in a general healthcare population. Am J Cardiol 106, 963-968.

21. Kunutsor SK, Apekey TA \& Steur M (2013) Vitamin D and risk of future hypertension: meta-analysis of 283,537 participants. Eur J Epidemiol 28, 205-221.

22. Scragg R, Sowers $M$ \& Bell C (2007) Serum 25-hydroxyvitamin D, ethnicity, and blood pressure in the
Third National Health and Nutrition Examination Survey. Am J Hypertens 20, 713-719.

23. Chiu KC, Chu A, Go VLW et al. (2004) Hypovitaminosis D is associated with insulin resistance and $\beta$ cell dysfunction. Am J Clin Nutr 79, 820-825.

24. von Hurst PR, Stonehouse W \& Coad J (2010) Vitamin D supplementation reduces insulin resistance in South Asian women living in New Zealand who are insulin resistant and vitamin D deficient - a randomised, placebo-controlled trial. Br J Nutr 103, 549-555.

25. Zemel MB, Shi H, Greer B et al. (2000) Reguatlion of adiposity by dietary calcium. FASEB J 14, 1132-1138.

26. Soares MJ, Chan She Ping-Delfos W \& Ghanbari MH (2011) Calcium and vitamin D for obesity: a review of randomized controlled trials. Eur J Clin Nutr $\mathbf{6 5}$, 994-1004.

27. Soares MJ, Murhadi LL, Kurpad AV et al. (2012) Mechanistic roles for calcium and vitamin $\mathrm{D}$ in the regulation of body weight. Obes Rev 13, 592-605.

28. Soares MJ, Pathak K \& Calton EK (2014) Calcium and vitamin $\mathrm{D}$ in the regulation of energy balance: where do we stand? Int J Mol Sci 15, 4938-4945.

29. Soares MJ, Ping-Delfos WC, Sherriff JL et al. (2011) Vitamin $\mathrm{D}$ and parathyroid hormone in insulin resistance of abdominal obesity: cause or effect? Eur J Clin Nutr $\mathbf{6 5}$, 1348-1352.

30. Major GC, Alarie F, Dore J et al. (2007) Supplementation with calcium + vitamin D enhances the beneficial effect of weight loss on plasma lipid and lipoprotein concentrations. Am J Clin Nutr 86, 54-59.

31. Calton EK, Pathak K, Soares MJ et al. (2015) Vitamin D status and insulin sensitivity are novel predictors of resting metabolic rate: a cross-sectional analysis in Australian adults. Eur J Nutr (Epublication ahead of print version).

32. Pittas AG, Dawson-Hughes B, Li T et al. (2006) Vitamin D and calcium intake in relation to type 2 diabetes in women. Diabetes Care 29, 650-656.

33. Davies KM, Heaney RP, Recker RP et al. (2000) Calcium intake and body weight. J Clin Endocrinol Metab 85, 4635-4638.

34. Drolet R, Richard C, Sniderman AD et al. (2008) Hypertrophy and hyperplasia of abdominal adipose tissues in women. Int J Obes (Lond) 32, 283-291.

35. Institute of Medicine (2011) Dietary Reference Intakes for Calcium and Vitamin D. Washington, DC: The National Academies Press.

36. Department of Health (2012) The Victorian Health Monitor. Melbourne: State Government of Victoria.

37. Kelsall LM, de Gooyer TE, Carey M et al. (2013) Blood lead levels in the adult Victorian population: results from the Victorian Health Monitor. Aust N Z J Public Health 37, 233-237.

38. Australian Bureau of Statistics (2013) Australian Health Survey: Users' Guide 2011-13. Canberra: ABS.

39. Dunstan DW, Zimmet PZ, Welborn TA et al. (2002) The Australian Diabetes, Obseity and Lifestyle Study (AusDiab) methods and response rates. Diabetes Res Clin Pract 57, 119-129.

40. Department of Health (2012) Victorian Population Health Survey 2010. Melbourne: State Government of Victoria.

41. Department of Health (2014) Victorian Population Health Survey 2011-12, Survey Findings. Melbourne: State Government of Victoria.

42. World Health Organization (1999) Diabetes and NonCommunicable Disease Risk Factor Surveys - A Field Guide. Geneva: WHO.

43. Department of Health (2012) The Victorian Health Monitor Food and Nutrition Report. Melbourne: State Government of Victoria. 
44. American Diabetes Association (2010) Diagnosis and classification of diabetes mellitus. Diabetes Care 33, Suppl. 1, S62-S69.

45. Food Standards Australia New Zealand (2007) AUSNUT 2007: Australian Food, Supplement \& Nutrient Database 2007 for Estimation of Population Nutrient Intakes. Canberra: FSANZ.

46. Armstrong T, Bauman A \& Davies J (2000) Physical Activity Patterns of Australian Adults: Results of the 1999 National Physical Activity Survey. Canberra: Australian Institute of Health and Welfare.

47. Markwick A, Ansari Z, Sullivan M et al. (2015) Social determinants and psychological distress among Aboriginal and Torres Strait Islander adults in the Australian state of Victoria: a cross-sectional population based study. Soc Sci Med 128, 178-187.

48. Hypponen E, Boucher BJ, Berry DJ et al. (2008) 25-Hydroxyvitamin D, IGF-1 and metabolic syndrome at 45 years of age. Diabetes 57, 298-305.

49. Yesil A \& Yilmaz Y (2013) Review article: coffee consumption, the metabolic syndrome and non-alcoholic fatty liver disease. Aliment Pharmacol Ther 38, 1038-1044.

50. Reis JP, von Muhlen D \& Miller ER 3rd (2008) Relation of 25-hydroxyvitamin D and parathyroid hormone levels with metabolic syndrome among US adults. Eur J Endocrinol 159, 41-48.

51. Ford ES, Ajani UA, McGuire LC et al. (2005) Concentrations of serum vitamin $\mathrm{D}$ and the metabolic syndrome among US adults. Diabetes Care 28, 1228-1230.

52. Gradillas-García A, Álvarez J, Rubio JA et al. (2015) Relationship between vitamin D deficiency and metabolic syndrome in adult population of the Community of Madrid. Endocrinol Nutr 62, 180-187.

53. Vitezova A, Zillikens MC, van Herpt TT et al. (2015) Vitamin $\mathrm{D}$ status and metabolic syndrome in the elderly: the Rotterdam Study. Eur J Endocrinol 172, 327-335.

54. Heaney RP (2008) Vitamin D and calcium interactions: functional outcomes. Am J Clin Nutr 88, issue 2, 541S-544S

55. Lips P (2012) Interaction between vitamin D and calcium. Scand J Clin Lab Invest Suppl 243, 60-64.

56. Norman AW (1990) Intestinal calcium absorption: a vitamin D-hormone-mediated adaptive response. Am J Clin Nutr 51, 290-300.

57. Shapses SA, Sukumar D, Schneider SH et al. (2012) Hormonal and dietary influences on true fractional calcium absorption in women: role of obesity. Osteoporos Int 23, 2607-2614

58. Ahlström T, Hagström E, Larsson A et al. (2009) Correlation between plasma calcium, parathyroid hormone (PTH) and the metabolic syndrome (MetS) in a community-based cohort of men and women. Clin Endocrinol (Oxf) 71, 673-678.

59. Huang C, Shapses S \& Wang X (2013) Association of plasma parathyroid hormone with metabolic syndrome and risk for cardiovascular disease. Endocr Pract 19, 712-717.

60. Durazo-Arvizu RA, Dawson-Hughes B, Sempos CT et al. (2010) Three-phase model harmonizes estimates of the maximal suppression of parathyroid hormone by 25 -hydroxyvitamin $\mathrm{D}$ in persons 65 years of age and older. J Nutr 140, 595-599.

61. Lucas R \& Neale R (2014) What is the optimal level of vitamin D? Aust Fam Physician 43, 119-122.

62. Mason C, Xiao L, Imayama I et al. (2014) Vitamin $\mathrm{D}_{3}$ supplementation during weight loss: a double-blind randomized controlled trial. Am J Clin Nutr 99, 1015-1025.

63. Cade C \& Norman AW (1986) Vitamin D 3 improves impaired glucose tolerance and insulin secretion in the vitamin D-deficient rat in vivo. Endocrinology 119, 84-90.
64. Cavalier E, Delanaye P, Souberbielle JC et al. (2011) Vitamin D and type 2 diabetes mellitus: where do we stand? Diabetes Metab 37, 265-272.

65. Norman AW, Frankel BJ, Heldt AM et al. (1980) Vitamin D deficiency inhibits pancretic secretion of insulin. Science 209, 823-825.

66. Mathieu C, Gysemans C, Giulietti A et al. (2005) Vitamin D and diabetes. Diabetologia 48, 1247-1257.

67. Palomer X, Gonzalez-Clemente JM, Blanco-Vaca F et al. (2008) Role of vitamin D in the pathogenesis of type 2 diabetes mellitus. Diabetes Obes Metab 10, 185-197.

68. Procopio M \& Borretta G (2003) Derangement of glucose metabolism in hyperparathyroidism. J Endocrinol Invest 26, 1136-1142.

69. Cozzolino M, Ketteler M \& Zehnder D (2010) The vitamin D system: a crosstalk between the heart and kidney. Eur $J$ Heart Fail 12, 1031-1041.

70. Merke J, Milde P, Lewicka S et al. (1989) Identification and regulation of 1,25 -dihydroxyvitamin $\mathrm{D}_{3}$ receptor activity and biosynthesis of 1,25-dihydroxyvitamin $\mathrm{D}_{3}$. J Clin Invest 83, 1903-1915.

71. Vaidya A, Forman JP \& Williams JS (2011) Vitamin D and the vascular sensitivity to angiotensin II in obese Caucasians with hypertension. J Hum Hypertens 25, 672-678.

72. Nasser M (2009) The metabolic syndrome: insulin resistance. Curr Hypertens Rep 11, 156-158.

73. Schmieder RE, Hilgers KF, Schlaich MP et al. (2007) Reninangiotensin system and cardiovascular risk. Lancet 369 , $1208-1219$.

74. Ullah MI, Uwaifo GI, Nicholas WC et al. (2010) Does vitamin D deficiency cause hypertension? Current evidence from clinical studies and potential mechanisms. Int $J$ Endocrinol 2010, 579-640.

75. Giallauria F, Milaneschi Y, Tanaka T et al. (2012) Arterial stiffness and vitamin D levels: the Baltimore longitudinal study of aging. J Clin Endocrinol Metab 97, 3717-3723.

76. Lee JI, Oh SJ, Ha WC et al. (2012) Serum 25-hydroxyvitamin $\mathrm{D}$ concentration and arterial stiffness among type 2 diabetes. Diabetes Res Clin Pract 95, 42-47.

77. Alyami A, Soares MJ, Sherriff JL et al. (2014) Vitamin D \& endothelial function. Indian J Med Res 140, 483-490.

78. Leung PS (2016) The potential protective action of vitamin $\mathrm{D}$ in hepatic insulin resistance and pancreatic islet dysfunction in type 2 diabetes mellitus. Nutrients $\mathbf{8}, 1-13$.

79. Gonzalez JT, Rumbold PL \& Stevenson EJ (2012) Effect of calcium intake on fat oxidation in adults: a meta-analysis of randomized, controlled trials. Obes Rev 13, 848-857.

80. Christensen R, Lorenzen JK, Svith CR et al. (2009) Effect of calcium from dairy and dietary supplements on faecal fat excretion: a meta-analysis of randomized controlled trials. Obes Rev 10, 475-486.

81. Lai YH \& Fang TC (2013) The pleiotropic effect of vitamin D. ISRN Nephrol 2013, 898125.

82. Calton EK, Keane KN, Newsholme P et al. (2015) The impact of vitamin D levels on inflammatory status: a systematic review of immune cell studies. PLoS One 10, e0141770.

83. Australian Bureau of Statistics (2015) Australian Health Survey: Usual Nutrient Intakes, 2011-12. Canberra: ABS.

84. Kurth T \& Sonis J (2007) Assessment and control of confounding in trauma research. J Trauma Stress 20, 807-820.

85. Speeckaert M, Huang G, Delanghe JR et al. (2006) Biological and clinical aspects of the vitamin $\mathrm{D}$ binding protein (Gc-globulin) and its polymorphism. Clin Chim Acta 372, 33-42.

86. Lauridsen AL, Vestergaard P, Hermann AP et al. (2005) Plasma concentrations of 25-hydroxy-vitamin D and 1,25dihydroxy-vitamin $\mathrm{D}$ are related to the phenotype of Gc (vitamin D-binding protein): a cross-sectional study on 595 early postmenopausal women. Calcif Tissue Int 77, 15-22. 
87. Boucher BJ (2012) Is vitamin D status relevant to metabolic syndrome? Dermatoendocrinology 4, 212-224.

88. Fu L, Yun F, Oczak M et al. (2009) Common genetic variants of the vitamin D binding protein (DBP) predict differences in response of serum 25-hydroxyvitamin D [25(OH)D] to vitamin D supplementation. Clin Biochem 42, 1174-1177.

89. Arnaud J \& Constans J (1993) Affinity differences for vitamin D metabolites associated with the genetic isoforms of the human serum carrier protein (DBP). Hum Genet 92, 183-188.

90. Hypponen E, Berry DJ, Wjst M et al. (2009) Serum 25-hydroxyvitamin D and IgE - a significant but nonlinear relationship. Allergy 64, 613-620.
91. Tseng CH (2010) Betel nut chewing and incidence of newly diagnosed type 2 diabetes mellitus in Taiwan. BMC Res Notes 3, 228

92. Boucher BJ, Ewen SWB \& Stowers JM (1994) Betel nut (Areca catechu) consumption and the induction of glucose intolerance in adult CD1 mice and in their F1 and F2 offspring. Diabetologia 37, 49-55.

93. Mann J (2002) Discrepancies in nutritional recommendations: the need for evidence based nutrition. Asia Pac J Clin Nutr 11, Suppl. 3, S510-S515.

94. Truswell AS (2001) Levels and kinds of evidence for publichealth nutrition. Lancet 357, 1061-1062. 